\title{
Legal Protection of Women as Victim of
} Domestic Violence

\author{
Case Study of Women and Children Service Units, Criminal Unit \\ of Gorontalo City Police
}

\author{
Fence M Wantu ${ }^{1 *}$, Mohamad Taufiq Zulfikar Sarson² \\ ${ }^{1}$ Faculty of Law, Universitas Negeri Gorontalo, Indonesia \\ *Corresponding Author: Fence M Wantu, email: fence_wantu@gmail.com
}

\begin{abstract}
This study aims to determine the extent of legal protection by the Women and Children Service Unit (PPA) of the Gorontalo City Resort Police Criminal Investigation Unit against women as victims of domestic violence and to find out what factors are obstacles to the efforts of the PPA Unit of the Criminal Investigation Unit Gorontalo Resort Police in tackling violence against women victims of Domestic Violence. Data collected through interviews and library research. Analysis of the data used is the data obtained will be analysed descriptively qualitatively describing the data obtained from field research (primary data), tested the truth then linked and analysed qualitatively with data obtained from library research (secondary). The results showed a form of legal protection by the PPA Unit of the Gorontalo Police Resort Criminal Investigation Unit against women as victims of domestic violence, namely preventive efforts by holding legal counselling in collaboration with the local government and further optimizing the performance of the Gorontalo City Resort Police Especially the PPA unit, repressive efforts that are in accordance with the rules of the Domestic Violence Protection Act. What factors hinder the efforts of the PPA Unit of the Gorontalo District Police Resort Criminal Investigation Unit in tackling violence against women victims of Domestic Violence, among others: legal factors themselves, law enforcement officer factors, factors or facilities that support law lnforcement, and society and culture factors.
\end{abstract}

Keywords: Domestic Violence, Women, Children, Legal Proection

\section{How to cite:}

Wantu, F.M., \& Sarson, M.T.Z (2020). Legal Protection of Women as Victim of Domestic Violence. Indonesian Journal of Advocacy and Legal Services, 1(2), 243-258. DOI: 10.15294/ijals.v1i2.36093 


\section{A. Introduction}

Marriage as a legal act between husband and wife, not only to realize worship to Allah SWT, but at the same time cause the legal consequences of civil law between the two. However, because the purpose of such a noble marriage is to foster a happy, everlasting, eternal family based on the Godhead, it is necessary to regulate the rights and obligations between each husband and wife. If their rights and obligations are fulfilled, then the desire of marriage based on love and affection will be realized. ${ }^{1}$

The concept of "family" is usually inseparable from the following four perspectives: (1) nuclear family; that the family institution consists of three main components, husband, wife and children, (2) a harmonious family, (3) the family is a continuation of generations (4) the family is the integrity of marriage. From these four perspectives it can be concluded that the family institution (household) is a unit consisting of father, mother (who is bound in marriage), children who are closely related to the elements of grandparents and other siblings, all showing their unity through harmony and a clear division of roles. ${ }^{2}$

The household should be a safe place for its members, because the family is built by husband and wife on the basis of the inner and outer bonds between the two. According to Article 33 of Law No. 1 of 1974 concerning marriage (Marriage Law) that: "Between husband and wife have an obligation to love, love, respect, and give assistance to one another physically and mentally." ${ }^{3}$ However, in reality many households have become places of suffering and torture due to violence.

Violence against a wife in a household is often considered a hidden crime by criminologists. Even though it has taken quite a number of victims from various sections of the community, domestic violence (hereinafter abbreviated as domestic violence), is still a serious social problem that does not receive the attention of the community, because: (1) Domestic violence has a relatively closed (private) scope and privacy is maintained because the problem occurs in the household (family). (2) Domestic violence is often considered reasonable because of the belief that treating the wife as he

Ahmad Rofiq, Hukum Islam di Indonesia, PT Raja Grafindo Persada, Jakarta,1998, p. 181.

2 Elli Nurh Ayati, Tantangan keluarga pada Mellenium ke-3, on Lusi Margiani \& Muh. Yasir Alimi (ed.), Sosialisasi Menjinakkan "Taqdir"Mendidik Anak Secara Adil, LSPPA, Yogyakarta, 1999, pp. 229-230; Choirunnisa Nur Novitasari, Dian Latifiani, Ridwan Arifin, Analisis Hukum Islam terhadap Faktor Putusnya Tali Perkawinan, SAMAAH: Jurnal Hukum Keluarga dan Hukum Islam, Vol. 3 No. 2, 2019, pp. 322-341.

3 Law Number 1 of 1974 concerning Marriage (Marriage Law) 
wishes is the husband's right as the leader and head of the household. (2) Domestic violence occurs in legal institutions, namely marriages.

Acts of violence on wives in the household is a serious social problem, but it does not get a response from the community and law enforcement for several reasons, first: the absence of accurate criminal statistics, second: acts of violence on wives in the household have a very scope privacy and privacy related to the sanctity of the home, third: acts of violence on wives are considered reasonable because the husband's rights as leaders and heads of families, fourth: acts of violence on wives in the household occur in legal institutions, namely marriages. ${ }^{4}$

The issue of domestic violence is one of the phenomena of various types of violence that occur today. As with other cases of violence that continue to increase, domestic violence is increasing from year to year. The phenomenon of violence against families can occur at anytime, anywhere, and under any circumstances. This violence includes physical and non-physical violence, sexual and economic violence.

Legal protection for women from violence, especially violence has been regulated in various national legal instruments. Legal substance related to violence against women can be seen in the Criminal Code (KUHP). At the Criminal Code there are several Articles that are directly related and can be qualified as acts of physical violence against women, namely, Article 351 of the Criminal Code up to Article 356 of the Criminal Code. Acts that fulfil the element of offense in these articles can be categorized as committing acts of violence in part in general nature. In addition to the Criminal Code which provides legal protection for female victims of physical violence also regulated in Article 6 states that: "Physical violence as intended in Article 5 letter $\mathrm{a}$ is an act that results in pain, illness, or serious injury". Then in Article 16 regarding the protection of victims states that: (1) within $1 \times 24$ (one time twenty-four) hours from knowing or receiving reports of domestic violence, the police must immediately provide temporary protection to victims. (2) Temporary protection as referred to in paragraph (1) is given no later than 7 (seven) days after the victim is received or handled. (3) Within $1 \times 24$ (once twenty-four) hours from the date of granting protection as referred to in paragraph (1), the police must request a letter establishing the protective order from the court.

Legal protection for women from violence, especially violence has been regulated in various national legal instruments. Legal substance related to

4 Hasbianto, Elli N, Kekerasan Dalam Rumah Tangga, Mizan Khasanah Ilmu-Ilmu Islam, Jakarta, 1996, p. 31; Khisbiyah Mohamad, Melawan Kekerasan Tanpa Kekerasan, The Asia Foundation-Pustaka Pelajar, Yogyakarta, 2000, pp. 45-47. 
violence against women can be seen in the Criminal Code (KUHP). At the Criminal Code there are several Articles that are directly related and can be qualified as acts of physical violence against women, namely, Article 351 of the Criminal Code up to Article 356 of the Criminal Code. Acts that fulfill the element of offense in these articles can be categorized as committing acts of violence in part in general nature. In addition to the Criminal Code which provides legal protection for female victims of physical violence also regulated in Article 6 states that: "Physical violence as intended in Article 5 letter $\mathrm{a}$ is an act that results in pain, illness, or serious injury". Then in Article 16 regarding victim protection states that: (1). within 1x24 (one time twenty-four) hours from knowing or receiving reports of domestic violence, the police must immediately provide temporary protection to victims. (2). Temporary protection as referred to in paragraph (1) is given no later than 7 (seven) days after the victim is received or handled. (3). Within 1x24 (one time twenty-four) hours from the date of granting protection as referred to in paragraph (1), the police are required to request a letter stipulating a protection order from the court.

The Domestic Violence Protection Law was made in order to eliminate discrimination against women. The enactment of several laws and regulations as a legal instrument to protect women from violence, but in practice it cannot guarantee the legal protection of women from physical violence. Legal instruments have not been able to be the basis for guaranteeing legal protection for women.

Protection that is expected by the victim is protection that can provide a sense of justice for the victim. Domestic violence where the majority of victims are women is, in principle, one of the phenomena of human rights violations so that this problem is a form of discrimination, especially against women and is a crime whose victims need protection from both government officials and the community. Legal protection for women victims of domestic violence still causes problems, especially in recognizing provisions in criminal law that require a criminal act to be prosecuted only because of a complaint. 5

In fact, law enforcement officials, namely the Indonesian National Police, have tried to minimize the problem of domestic violence through

5 Andi Hamzah, Perlindungan Hak-Hak Asasi Manusia dalam KUHAP, Bina Cipta, . Bandung, 1986, p. 112; Andi Zainal Abidin Farid, Bunga Rampai Hukum Pidana, Pradnya Paramita, Jakarta, 1983, pp. 27-30; Andi Zainal Abidin Farid, Hukum Pidana I, Sinar Grafika, Jakarta, 1995, pp. 35-36; Ridwan Arifin \& Lilis Eka Lestari, Penegakan Dan Perlindungan Hak Asasi Manusia Di Indonesia Dalam Konteks Implementasi Sila Kemanusiaan Yang Adil Dan Beradab, Jurnal Komunikasi Hukum (JKH), Vol. 5 No. 2, 2019, pp. 12-25. 
KAPOLRI Regulation No. 10 of 2007 concerning Organization and Work Procedures. Based on these regulations, a unit was formed to provide services, protection for women and children, which is called the Women's and Children's Service Unit (PPA Unit). The PPA Unit is located under the Criminal Investigation Unit (Sat Reskrim) of the Resort Police. The main task of the PPA Unit is to provide services in the form of protection of women and children who are victims of crime or violence and enforce the law against perpetrators. In carrying out its duties, the PPA Unit carries out functions as the organization of services and legal protection, the conduct of investigations and criminal investigations, the implementation of cooperation and coordination with related agencies. In carrying out their duties, the PPA Unit is led by Kanit (Unit Head) in organizing the protection of women and children who are victims of crime and law enforcement against perpetrators. With the establishment of the PPA Unit, it is expected to be able to support the realization and protection of domestic violence against women.

\section{B. Method}

Based on the background of the above problems, the problems in writing this research are: What is the form of legal protection by the PPA Unit of Reskrim Police of Gorontalo City against women as victims of domestic violence and what factors are hampering the efforts of the Sat Reskrim PPA Unit Gorontalo city police in tackling violence against women victims of domestic violence?

The location of the research will be carried out in Gorontalo City, Gorontalo Province more precisely in the jurisdiction of Gorontalo Municipal Police, Gorontalo Province. Specifically, the Women's and Children's Protection Unit of Gorontalo City Police

Population is all objects or all individuals or all symptoms or all occurrences or all units to be examined. ${ }^{6}$ The population in this study are those who are related to legal protection against women as victims of domestic violence "(study in the Women's and Children's Services unit of the Gorontalo City Police Criminal Investigation Unit), by using this population accurate data will be obtained and appropriate in this research.

The sampling method used by the author in this study is a non random sampling technique. In using this technique, certain characteristics or characteristics which are the main characteristics of the population are

6 Ronny Hanitijo Soemitro, Metode Penelitian Hukum dan Jurimetri, Ghalia Indonesia, Jakarta, 1988, p. 44. 
determined, then the subjects taken as samples must really be subjects that contain many of the main characteristics of the population.

The sampling technique used in this research is Non Random Sampling, with Purposive Sampling, which is withdrawal of the sample by taking subjects based on specific objectives. The reason the author uses this sampling technique is because the respondent is considered to really know about legal protection against women as victims of domestic violence"(study in the Women's and Children's Services unit of the Gorontalo City Police Criminal Investigation Unit), thus the sample selected later Respondents in this study were as follows: (1) Society or women victims of Gorontalo city domestic violence, (2) Gorontalo City Police Particularly in Gorontalo City Women's and Children's Services Unit, (3) Lecturers / Teaching Staff of the Faculty of Law, Gorontalo State University.

Data collection techniques used in this study are divided into two, including (1) Field Research In conducting field research, the writer takes two ways, namely Observation and Interviewing (2) Research Library (Research Library) Research library research through library research data collection techniques (Library Research) is done by collecting various data from relevant literature.

In accordance with the problems to be answered and the objectives to be achieved in this study, the data obtained will be analyzed descriptively qualitatively that is describing the data obtained from field research (primary data), tested the truth then linked and analyzed qualitatively with data obtained from library research (secondary)

\section{Result and Discussion}

1. Legal Protection for Victim of Crime

The concept of legal protection is given to legal subjects in the form of instruments both preventive and repressive, both oral and written. In other words it can be said that legal protection as a separate description of the function of the law itself, which has the concept that the law provides for justice, order, certainty, usefulness and peace. ${ }^{7}$

In carrying out and providing legal protection the need for a place or container in its implementation which is often referred to as legal protection means, means of legal protection are divided into two types that can be understood, as follows: (1) Means of Preventive Legal Protection, In this preventive legal protection, legal subjects are given the opportunity to raise

Indah Sri Utari \& Ridwan Arifin, Law Enforcement and Legal Reform in Indonesia and Global Context: How the Law Responds to Community Development?, Journal of Law and Legal Reform, Vol. 1 No. 1, 2019, pp. 1-4. 
their objections or opinions before a government decision gets a definitive form. The aim is to prevent disputes. Preventive legal protection means a great deal of governmental action based on freedom of action because with preventive legal protection the government is driven to be careful in making decisions based on discretion. In Indonesia there are no specific arrangements regarding preventive legal protection. (2) Means of Repressive Legal Protection, repressive legal protection aims to resolve disputes. The handling of legal protection by the General Courts and Administrative Courts in Indonesia falls into this category of legal protection. The principle of legal protection against government actions rests and stems from the concept of the recognition and protection of human rights. ${ }^{8}$

Law Enforcement Theory can also be interpreted by law enforcement officers and by anyone who has an interest in accordance with their respective authorities according to applicable law. Criminal law enforcement is a unified process that begins with the investigation, arrest, detention, trial of the accused and ends with the conviction of the convicted person. ${ }^{9}$

Criminal law enforcement is the concrete application of criminal law by law enforcement officials. In other words, the enforcement of criminal law is the implementation of criminal regulations. Thus, law enforcement is a system that involves harmonizing the values with the rules and real human behavior. These rules then become guidelines or benchmarks for behavior or actions that are considered appropriate or appropriate. The behavior or attitude of the action aims to create, maintain, and maintain peace.

\section{Form of Legal Protection by PPA Unit of Gorontalo City Resort Police Criminal Investigation Unit against Women as Victims of Domestic Violence}

According to the results of the research in the field factors that influence the number of acts of violence against women in the household are: (1) Economic Factors Women who come from households with lower welfare levels tend to have a higher risk of experiencing physical and/or sexual violence by a partner. Women who come from households in the poorest $25 \%$ have a 1.4 times greater risk of experiencing physical and/or sexual violence by a partner than the richest $25 \%$. The economic aspect is the more

Hasbianto, Elli N. Op.Cit., p. 102

9 Harun M. Husen, Kejahatan dan Penegakan Hukum Di Indonesia, Rineka Cipta, Jakarta, 1990, p. 58; CST. Kansil, Pengantar Ilmu Hukum dan Tata Hukum Indonesia, Balai Pustaka, Jakarta, 1989, pp. 57-59. 
dominant aspect being a factor of violence against women compared to the education aspect. (2) Sub-standard Communication Factors between husband and wife in solving problems in the household, so that disputes between husband and wife often occur due to misunderstanding between the two parties. (3) The low understanding of religion in the household is one of the factors that causes many acts of violence against women, the husband who should be a good household leader should educate women based on religious teachings, not by committing violence so that the wife obeys all orders husband (4) Parent factor is one of the factors causing violence, parents are too meddling in their children's household affairs so that in many marriages there are fights caused by too many parents interfering in various things in the household. (5) Husbands often consume alcohol as a factor causing violence against women, many cases of husbands beating their wives in an unconscious or drunken state. (6) The existence of a third person in the household is also a factor causing a lot of violence against women. The third person triggers quarrels in the household, the household becomes out of harmony, the neglect in the household due to a third person. 10

Seeing that acts of violence often occur, then as victims of crime, victims are obliged to get protection for the acts they experienced. As law enforcers, the Women's and Children's Services Unit (PPA) contained in Gorontalo City Police is expected to make it easier for victims of domestic violence to obtain protection. In terms of how the forms of protection for women victims of domestic violence are carried out by the Unti PPA Sat Reskrim Gorontalo District Police Precinct based on interviews conducted there are several kinds of ways including:

Based on the Domestic Violence Protection Law contained in article 16 namely temporary protection which states that: (1) Within 1 x 24 (one time twenty-four) hours from knowing or receiving reports of domestic violence, the police must immediately provide temporary protection to victim. (2) Temporary protection as referred to in paragraph (1) is given no later than 7 (seven) days after the victim is received or handled. (3) Within 1 x 24 (one time twenty-four) hours from the date of granting protection as referred to in paragraph (1), the police are required to request a letter stipulating a protection order from the court.

10 Alycia Sandra Dina Andhini \& Ridwan Arifin, Analisis Perlindungan Hukum Terhadap Tindak Kekerasan pada Anak di Indonesia, Ajudikasi: Jurnal Ilmu Hukum, Vol. 3 No. 1, 2019, pp. 41-52; Meita Agustin Nurdiana \& Ridwan Arifin, tindak Pidana Pemerkosaan: Realitas Kasus Dan Penegakan Hukumnya Di Indonesia (Crime of Rape: Case Reality and Law Enforcement in Indonesia), Literasi Hukum, Vol. 3 No. 1, 2019, pp. 52-63. 
Temporary protection, namely protection directly provided by the police, namely by cooperating with health workers, one of which is from health workers checking the victim's condition. Then from the police conduct an investigation after knowing and receiving reports that there has been domestic violence. Furthermore, the protection provided by the police is also in the form of notification of the progress of the case being handled by the police to the victim or the victim's family. ${ }^{11}$

In providing temporary protection, the police can work together with health workers, social workers, volunteer assistants, and/or spiritual mentors to assist victims. ${ }^{12}$ In addition, the police are required to provide information to victims about the right of victims to receive services and assistance. ${ }^{13}$ The police also immediately told the victims about: the identity of officers for the introduction of victims of domestic violence as crimes against human dignity, and the obligation of the police to protect victims. ${ }^{14}$ In order for this temporary protection to be upgraded to protection, within 1 $\mathrm{x} 24$ hours from the time the temporary protection is granted, the police must request a letter of protection order from the court.

In addition to temporary protection from the police, and permanent protection by the court, as well as assistance for the process of spiritual guidance and advocacy for victims in the legal process, other efforts that are part of the protection of victims of domestic violence are punishing perpetrators in accordance with forms of domestic violence that he committed the victim, because the act of domestic violence was a crime. ${ }^{15}$

Law enforcement against acts of domestic violence is carried out by arresting and detaining perpetrators (husbands) who are allegedly violating the protection order for victims (wives), without waiting for arrest and arrest warrants. It is feared that the victim will get further acts of violence from the perpetrators if they have to wait for an arrest warrant. To fulfil the procedure of criminal procedure, a warrant for arrest and detention can be given after $1 \times 24$ hours. The rigid nature of the rule of law is sometimes less protective of victims. Thus the existence of the provisions of Article 35 of this Law is essentially paying attention to the reality of legal protection

11 Nur Moh. Kasim, Sri Nanang Meiske Kamba, Implementation of Assistance for Victims of Domestic Violence, Indonesian Journal of Advocacy and Legal Services, Vol. 1 No.1, 2019, pp.147-156. DOI: https://doi.org/10.15294/ijals.v1i1.33801

12 Article 17 of Law Number 23 of 2004

13 Article 18 of Law Number 23 of 2004

14 Article 20 of Law Number 23 of 2004

15 Moerti Hadiati Soeroso, Kekerasan Dalam Rumah Tangga dalam Perspektif YuridisViktimologis, Sinar Grafika, Jakarta, 2010, pp. 25-26; Nursyahbani Katjasungkana, Kasus-Kasus Hukum Kekerasan Terhadap Perempuan, Galang Printika, Yogyakarta, 2002, pp. 45-46. 
for victims of crime so far. Because of the law provides more protection to the perpetrators of crime as regulated in criminal procedure law. ${ }^{16}$

Thus this law is very concerned about the fate of victims without ignoring the rights of husband and wife in domestic relations. Because victims who receive temporary protection and court protection are intended to provide a sense of "security" to the victim, without having to separate the victim (wife) from the perpetrator (husband) if the perpetrator is believed to obey the protective order from the court. ${ }^{17}$

Protection of victims of domestic violence according to Indonesian criminal law in accordance with Law Number 23 of 2004, there are several stages, namely the preventive stage through temporary protection from the police and or court protection, placement of victims in "safe houses," and curative stages both physical and psychological health, and actions repressive towards perpetrators of domestic violence.

Preventive measures (prevention) are intended as an attempt to make changes that are positive towards the possibility of disturbances in order and security (legal stability). This preventive action is one of the most appropriate ways to be done by the police, government, and the community. This is due to the previous efforts so that it can reduce cases of domestic violence in the future. Preventive efforts can be made by (1) holding legal counseling in collaboration with local governments that can be done in various ways and forms, such as through the media, or directly holding lectures to the public that contain the legal consequences that will be experienced if someone is involved in a criminal case and there are also moral sanctions that will be given to offenders. (2) Optimizing the performance of the Gorontalo City Police Precinct in particular the PPA unit in serving, protecting and protecting the community.

Repressive measures (enforcement) are carried out at the time of the crime. In this case, the party most entitled and authorized to make this effort is the authorities, especially the police. In making this effort the police must be serious in taking action in the event of a domestic violence case. But before taking action against the perpetrators, the police must consider the severity of domestic violence committed by the perpetrators.

16 Abraham Abraham, Muhammad Ade Mirza Kurniawan, Andrew Mario Ernesto Ataupah, \& Ridwan Arifin, The Fallen of Justice: How Indonesia Survive With A Violation of Human Rights?, Kuala Lumpur International Multidisciplinary Academic Conference (KLIMAC 2019), 2019, pp. 229-235.

17 Leden Marpaung, Asas-Teori-Praktik Hukum Pidana, Sinar Grafika, Jakarta, 2008, p. 34; Moeljatno, Asas-asas Hukum Pidana, Bina Aksara, Jakarta, 1987, pp. 28-29. 


\section{Factors Hampered the Efforts of the PPA Unit of the Gorontalo} District Police Resort Criminal Investigation Unit in Addressing Violence Against Women Victims of Domestic Violence

Other factors which become obstacles in the legal protection of women victims of domestic violence include: (1) Legal Factors, Physical violence in the household is regulated in article 6 of Law Number 23 of 2004 concerning the Elimination of Domestic Violence, which referred to as physical violence is an act that results in pain, illness, or serious injury. ${ }^{18}$ The crime of physical violence is a complaint offense. Therefore physical violence cases can be tried in court if there is a complaint first. With the culture of the community, it seems the community will be thousands of times to bring the domestic violence case to court. There is a slight problem in this matter, because it turns out that in Law Number 23 of 2004 concerning the Elimination of Domestic Violence, no juridical understanding of pain, illness, or serious injury is found, even though this understanding is most important for determining and proving the type of acts committed by the perpetrators/suspects/defendants, therefore these understandings must be sought in the Criminal Code and Jurisprudence. ${ }^{19}$ The crime of physical violence is a complaint offense. Therefore physical violence cases can be tried in court if there is a complaint first. The still lack of socialization of Law Number 23 of 2004 concerning Domestic Violence Protection especially in Gorontalo City causes the community at large not to understand the meaning of eliminating violence in the household. Socialization is needed in order to internalize the new values brought by the Domestic Violence Protection Law. So far, the socialization has only been carried out in urban communities and tends to be elitist and still has not touched many ordinary people and grassroots, which often has the potential for domestic violence.

Meanwhile it is also unclear which agency is most responsible for internalizing the Domestic Violence Protection Law. In addition, Article 44 paragraph (4) of the Domestic Violence Protection Law allows a complaint offense to be revoked. (2) Many Law Enforcement Officers (police, prosecutors, judges) are still gender biased, often using victim blaming and victim participating approaches in responding to violence cases. Victims of violence have doubts, worries, and fears to report what happened. Victims are afraid of the legal process that will be undertaken. The gender

18 Philipus M. Hadjon, Perlindungan Hukum Bagi Rakyat Indonesia, CV. Agung Semarang, Jakarta, 1987, p. 68.

19 PAF Lamintang, Hukum Pidana Indonesia, Bina Cipta, Bandung, 1990, pp. 37-38; R.Soesilo, Kitab Undang-undang Hukum Pidana Serta Komentar-komentarnya Lengkap Pasal Demi Pasal, Politeae, Bogor, 1993, pp. 54-59. 
awareness and sensitivity of law enforcers is still lacking, so that sometimes victims become objects. The Integrated Criminal Justice System that is Gender Equitable in Handling Cases of Violence against Women (SPPTPKKTP) is an integrated system that shows the process of linkages between agencies/parties authorized to handle cases of violence against women and access to services that are easy and affordable for victims in each Court for case process violence against women. ${ }^{20}$ SPPT-PKKTP demands law enforcers who have gender equality vision and are not gender biased. Domestic violence cases are sometimes difficult to process. Usually having difficulty in proving evidence (witnesses are usually absent), the case is revoked by the victim himself (because of love/because of a livelihood case). In the police, there was a lack of readiness in handling domestic violence cases with its Special Service Room (RPK). Ideally cases of domestic violence are handled by female police. However, currently the number of policewomen is still very limited.

On the other hand, investigators themselves often face obstacles in handling domestic violence cases related to the absence of witnesses, making it difficult for the filing process and the weakness of the case if it reaches the court. ${ }^{21}$ (3) Facilities or Facilities Factors that Support Law Enforcement include, among others, educated and skilled human resources, good organization, adequate equipment, adequate finance and so on. In terms of facilities and facilities, in the jurisdiction of Gorontalo City Police there are NGOs engaged in the field of womanhood. However, it has not been able to be maximal in providing assistance, especially the vast area. In addition, there is no victim assistance by NGOs to provide assistance to victims in litigation and non-litigation. ${ }^{22}$ This assistance is important, because it can restore the victim's confidence, and also to restore trauma. (4) Community and Cultural Factors. The legal awareness of citizens to comply with the Domestic Violence Act is still very minimal. ${ }^{23}$

Some people do not want to realize that there is a law that prohibits violence against fellow family members. Even though some community members already know that the threat of imprisonment for perpetrators of domestic violence, it is still influenced by patriarchal culture or has power that exceeds the limits in the family. The level of legal awareness from the

20 Rika Saraswati, Perempuan dan Penyelesaian Kekerasan Dalam Rumah Tangga, Citra Aditya Bakti, Bandung, 2009, pp. 16-19.

21 Satjipto Rahardjo, Hukum dan Masyarakat, Angkasa, Jakarta, 1980, p. 45.

22 Sri Hartanto, Indah Sri Utari, \& Ridwan Arifin, Implementation of Penal Mediation in The Perspective of Progressive Law (Study at The Semarang City Police Department), IJCLS (Indonesian Journal of Criminal Law Studies), Vol. 4 No. 2, 2019, pp. 161-188.

23 S.R. Sianturi, Asas-asas Hukum Pidana di Indonesia Dan Penerapannya, Alumni Ahaem-Petehaem, Jakarta, 1996, pp. 23-24. 
community is still far from the expectation to eliminate domestic violence. So that many victims of domestic violence prefer divorce to end the domestic violence problem rather than expect a protracted investigation process with a high enough cost. Moreover, if we look at the practice in the field, how victims of domestic violence have not received adequate protection as regulated in laws and government regulations on domestic violence.

\section{Conclusion}

The form of legal protection by the PPA Sat Reskrim Unit of Gorontalo City Police for women as victims of domestic violence is preventive measures intended as an effort to make positive changes to the possibility of disturbances in order and security (legal stability). Preventive efforts can be done by holding legal counseling in collaboration with local governments that can be done in various ways and forms, such as through the media, or directly holding lectures to the public that contain the legal consequences that will be experienced if someone is involved in a criminal case and there are also moral sanctions that will be given to the perpetrators and more optimize the performance of the Gorontalo City Police Police in particular the PPA unit in serving, protecting and protecting the community. Then Repressive Efforts (Enforcement) are carried out at the time of the crime. In this case, the party most entitled and authorized to make this effort is the authorities, especially the police. In making this effort the police must be serious in taking action in the event of a domestic violence case. But before taking action against the perpetrators, the police must consider the severity of domestic violence committed by the perpetrators. What factors hinder the efforts of the PPA Sat Reskrim Unit of Gorontalo City Police in tackling violence against women victims of Domestic Violence, among others, the Legal Factor itself, Law Enforcement Officials Factors, Facilities That Support Law Enforcement, Community and Cultural Factors.

Based on the conclusions above, the authors provide some suggestions for the PPA Unit of Gorontalo City Police to make more efforts to improve the protection of victims of domestic violence by submitting a request for protection to the court for victims because even though the PPA Unit has sought several ways to provide protection to victims, the reality is still there are victims who experience repeated violence. Secondly, so that the police are more alert, responsive and friendly in handling cases of women and children it is necessary to increase knowledge and skills to handle cases of women and children through education and training. Third, in the face of limited human resources and police infrastructure to further enhance and 
expand the network of cooperation with networked institutions that deal with victims of violence. Then all parties, both the police, the attorney's office, the court, the central government, the regional government and the people who understand the law should be more socializing Law Number 23 of 2004 concerning the Elimination of Domestic Violence to the public, especially specifically to the police organizing a socialization regarding legal protection on the rights of victims of domestic violence so that as victims they do not need to feel afraid or pressured to report the crimes they experienced For the community to participate in preventing domestic violence, for example as neighbors if they know bickering / violence between husband and wife or other people in the household so attempt to prevent the quarrel, or report to the authorities if they know of domestic violence. As victims of domestic violence, victims should be quicker to report the crime they experienced so that as a law enforcement officer they act faster and get protection from the police.

\section{E. Acknowledgments}

Thanks to Universitas Negeri Goronatalo, Faculty of Law, and the Women and Children Service Unit (PPA) of the Gorontalo City Resort Police Criminal Investigation Unit for unvaluable inputs and suggestions, as well as data support for this research. Author also would like o express great thankfulness to Editorial Team Journal of Advocacy and Legal Services, Faculty of Law, Universitas Negeri Semarang, Indonesia.

\section{F. Declaration of Conflicting Interests}

The authors state that there is no potential conflict of interest in the research, authorship, and / or publication / publication of this article.

\section{G. Funding}

None

\section{H. References}

Abraham, A., Kurniawan, M.AM., Ataupah, A.M.E., \& Arifin, R. (2019). The Fallen of Justice: How Indonesia Survive With A Violation of Human Rights?, Kuala Lumpur International Multidisciplinary Academic Conference (KLIMAC 2019), 1(December 2019), 229-235. 
Andhini, A.S.D., \& Arifin, R. (2019). Analisis Perlindungan Hukum Terhadap Tindak Kekerasan pada Anak di Indonesia. Ajudikasi: Jurnal Ilmu Hukum, 3(1), 41-52. DOI: http://dx.doi.org/10.30656/ajudikasi.v3i1.992.

Arifin, R., \& Lestari, L.E. (2019) Penegakan Dan Perlindungan Hak Asasi Manusia Di Indonesia Dalam Konteks Implementasi Sila Kemanusiaan Yang Adil Dan Beradab, Jurnal Komunikasi Hukum (JKH), $\quad$ Vol. 5 No. 2, pp. 12-25. DOI: DOI: http://dx.doi.org/10.23887/jkh.v5i2.16497.

Farid, A.Z.A. (1983). Bunga Rampai Hukum Pidana. Jakarta: Pradnya Paramita.

Farid, A.Z.A. (1995). Hukum Pidana I. Jakarta: Sinar Grafika. Hadjon, P.M. (1987). Perlindungan Hukum Bagi Rakyat Indonesia. Jakarta: CV. Agung Semarang.

Hamzah, A. (1986). Perlindungan Hak-Hak Asasi Manusia dalam KUHAP. Bandung: Bina Cipta.

Hartanto, S., In Utari, I.S., \& Arifin, R. (2019). Implementation of Penal Mediation in The Perspective of Progressive Law (Study at The Semarang City Police Department). IJCLS (Indonesian Journal of Criminal Law Studies), 4(2), 161-188. DOI: DOI: https://doi.org/10.15294/ijcls.v4i2.21494.

Hasbianto, \& Elli, N. (1996). Kekerasan Dalam Rumah Tangga. Jakarta: Mizan Khasanah Ilmu-Ilmu Islam.

Husen, H.M. (1990). Kejahatan dan Penegakan Hukum Di Indonesia. Jakarta: Rineka Cipta.

Kansil, CST. (1989). Pengantar Ilmu Hukum dan Tata Hukum Indonesia. Jakarta: Balai Pustaka.

Kasim, N.M., \& Kamba, S.N.M. (2019). Implementation of Assistance for Victims of Domestic Violence. Indonesian Journal of Advocacy and Legal Services, 1(1), 147-156. DOI: https://doi.org/10.15294/ijals.v1i1.33801.

Katjasungkana, N. (2002). Kasus-Kasus Hukum Kekerasan Terhadap Perempuan. Yogyakarta: Galang Printika.

Lamintang, PAF. (1990). Hukum Pidana Indonesia. Bandung: Bina Cipta.

Law Number 1 of 1974 concerning Marriage (Marriage Law)

Law Number 23 of 2004 concerning the Elimination of Domestic Violence

Margiani, L. \& Alimi, M.Y. (ed.) (1999). Sosialisasi Menjinakkan “Taqdir”Mendidik Anak Secara Adil. Yogyakarta: LSPPA.

Marpaung, L. (2008). Asas-Teori-Praktik Hukum Pidana. Jakarta: Sinar Grafika.

Moeljatno, M. (1987). Asas-asas Hukum Pidana. Jakarta: Bina Aksara.

Mohamad, K. (2000). Melawan Kekerasan Tanpa Kekerasan. Yogyakarta: The Asia Foundation-Pustaka Pelajar.

Nurdiana, M.A., \& Arifin, R. (2019). Tindak Pidana Pemerkosaan: Realitas Kasus Dan Penegakan Hukumnya Di Indonesia (Crime of Rape: Case Reality and Law Enforcement in Indonesia). Literasi Hukum, 3(1), 
$52-63$.

Retrieved

from

http://jurnal.untidar.ac.id/index.php/literasihukum/article/view/1350.

Novitasari, C.N., Latifiani, D., \& Arifin, R. (2019). Analisis Hukum Islam terhadap Faktor Putusnya Tali Perkawinan. SAMARAH: Jurnal Hukum Keluarga dan Hukum Islam, 3(2), 322-341. DOI: http://dx.doi.org/10.22373/sjhk.v3i2.4441.

Rahardjo, S. (1980). Hukum dan Masyarakat. Jakarta: Angkasa.

Rofiq, A. (1998). Hukum Islam di Indonesia. Jakarta: PT Raja Grafindo Persada.

Saraswati, R. (2009). Perempuan dan Penyelesaian Kekerasan Dalam Rumah Tangga. Bandung: Citra Aditya Bakti.

Sianturi, S.R. (1996). Asas-Asas Hukum Pidana di Indonesia Dan Penerapannya. Jakarta: Alumni Ahaem-Petehaem.

Soemitro, R.H. (1988). Metode Penelitian Hukum dan Jurimetri. Jakarta: Ghalia Indonesia.

Soeroso, M.H. (2010). Kekerasan Dalam Rumah Tangga dalam Perspektif Yuridis-Viktimologis. Jakarta: Sinar Grafika.

Soesilo, R. (1993). Kitab Undang-undang Hukum Pidana Serta Komentarkomentarnya Lengkap Pasal Demi Pasal. Bogor: Politeae.

Utari, I.S., \& Arifin, R. (2019). Law Enforcement and Legal Reform in Indonesia and Global Context: How the Law Responds to Community Development? Journal of Law and Legal Reform, 1(1), 1-4. DOI: https://doi.org/10.15294/jllr.v1i1.35772

Copyrights (C) 2020 by Auhtor(s). This work is licensed under a Creative Commons Attribution-NonCommercial-ShareAlike 4.0 International License. All writings published in this journal are personal views of the authors and do not represent the views of this journal and the author's affiliated institutions. 